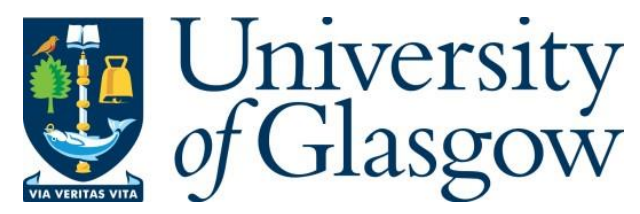

Dziallas, S., Fincher, S., Barr, M. and Cutts, Q. (2021) Learning in Context: a First Look at a Graduate Apprenticeship. In: 21st Koli Calling International Conference on Computing Education Research, 18-21 Nov 2021, p. 19. ISBN 9781450384889.

There may be differences between this version and the published version. You are advised to consult the publisher's version if you wish to cite from it.

(C) ACM 2021. This is the author's version of the work. It is posted here for your personal use. Not for redistribution. The definitive Version of Record was published in Proceedings of the 21st Koli Calling International Conference on Computing Education Research, 18-21 Nov 2021, p. 19. ISBN 9781450384889. https://doi.org/10.1145/3488042.3490020.

http://eprints.gla.ac.uk/256031/

Deposited on: 12 October 2021

Enlighten - Research publications by members of the University of Glasgow http://eprints.gla.ac.uk 


\title{
Learning in Context: A First Look at a Graduate Apprenticeship
}

\author{
Anonymous Author(s)
}

\begin{abstract}
In this paper, we examine a new Graduate Apprenticeship program. Graduate Apprenticeships (and degree-level apprenticeships more broadly) were established in the United Kingdom with the expressed goal of addressing the persistent skills gap, with employers facing difficulties in recruiting adequately skilled employees, and at the same time promoting opportunities for students who would not have otherwise pursued a computing degree.

We take a 360-degree view of this novel program and explore why the university chose to pursue it, why the employers decided to participate in it, and how the students are experiencing it. To do so, we draw on three kinds of data: life story interviews with students in the first cohort of the Graduate Apprenticeship that focus on the individual learning journeys that brought them to the program; a consultation and series of individual interviews with employers to examine their aims for participating in the program; a diary study with all apprentices over a period of four weeks to explore the kinds of work they were doing on a day-to-day basis in their companies.

In our "first look" at this program, we highlight aspects that make it particularly attractive to this student body and explore the actual work apprentices are doing in their companies after a year in the program. As well as providing local insight, we more broadly present this program in its context as an example of an evolutionary response to forces on an educational system.
\end{abstract}

\section{CCS CONCEPTS}

- Social and professional topics $\rightarrow$ Computer science education.

\section{KEYWORDS}

qualitative methods, narrative approach, diary study, work-based learning, graduate apprenticeship

\section{ACM Reference Format:}

Anonymous Author(s). 2018. Learning in Context: A First Look at a Graduate Apprenticeship. In Woodstock '18: ACM Symposium on Neural Gaze Detection, fune 03-05, 2018, Woodstock, NY. ACM, New York, NY, USA, 10 pages. https://doi.org/10.1145/1122445.1122456

\section{INTRODUCTION}

Work-based learning in the form of apprenticeships has been practiced for centuries. However, it has not typically been integrated into higher education curricula, where only degrees in vocational

Permission to make digital or hard copies of all or part of this work for personal or classroom use is granted without fee provided that copies are not made or distributed for profit or commercial advantage and that copies bear this notice and the full citation on the first page. Copyrights for components of this work owned by others than ACM must be honored. Abstracting with credit is permitted. To copy otherwise, or republish, to post on servers or to redistribute to lists, requires prior specific permission and/or a fee. Request permissions from permissions@acm.org.

Woodstock '18, June 03-05, 2018, Woodstock, NY

(c) 2018 Association for Computing Machinery.

ACM ISBN 978-1-4503-XXXX-X/18/06 .. \$15.00

https://doi.org/10.1145/1122445.1122456 subjects, such as medicine and law, traditionally require students to spend significant time in the workplace. In computing education, there is a continuum of practices that can expose students to aspects of professional practice, such as service learning, projectbased learning, and cooperative learning [16]. The umbrella term "cooperative learning" describes different kinds of placements, including internships and "sandwich" years - a popular model in the United Kingdom - when students spend a year in industry between their second and third (and final) year of study [15].

More recently, in the United Kingdom, work-based learning and degree programs have been increasingly presented as a means to address the perceived graduate skills gap, with statistics showing computing graduates having the highest unemployment rate of any subject six months after graduation [15], while at the same time employers report difficulties in recruiting adequately skilled employees [28]. In response, the government launched the Shadbolt review [28], which recommended "extending and promoting work experience" and "improving graduates' softer and work readiness skills". One route the review identified are so-called degree-level apprenticeships, which are paid positions that cover tuition fees and combine part-time work with study at university.

The government established these apprenticeships across the United Kingdom (as Graduate Apprenticeships in Scotland and as Degree Apprenticeships in the rest of the UK) in 2015 with the aim to create employer-led curricula and to increase the supply of skilled graduates [30]. As part of this goal, in 2017, it also instituted the Apprenticeship Levy, which requires organizations paying annual wages of more than GBP 3 million to contribute $0.5 \%$ of their annual wage bill to fund new apprenticeships. Government data indicates a steady growth in the uptake of these new programs [26].

\section{RELATED WORK}

Work-based learning has been implemented in a variety of disciplines and there is a substantial body of prior work [12]. However, work on degree-level apprenticeships remains limited, in part due to their young age. In computing education, degree-level apprenticeships have been studied as individual programs, often in the context of reports on the development of new programs, and as part of multi-institutional efforts to establish similarities more broadly.

In the former category, Barr and Parkinson describe an effort to design a new program in collaboration with industry and highlight the importance of engaging employers in the process [6]. Similarly, Sheen et al. developed a user experience (UX) program and report on the challenges of offering this during the COVID-19 pandemic [29]. However, there is also work exploring the student experience. For example, Taylor-Smith et al. investigate apprentices' identity as students and employees at one institution and found that "apprentices defined themselves in opposition to traditional student identities and did draw strength from their identity as employees", as well as their belonging within their cohort of apprentices [6].

In terms of multi-institutional efforts, a number of studies have focused on whether degree-level apprenticeships are able to attract 
students who otherwise would not have pursued a computing education. Initial findings from three institutions suggest that many participants were already in an IT career and used the apprenticeship to gain additional skills and a recognized qualification [33]. However, Smith et al. later surveyed apprentices at six institutions across Scotland and found that they came from all socio-economic backgrounds and included both those who had already worked in IT and those who were new to the sector. They identify the impact of employer selection as a key factor in social mobility and describe the apprenticeship as a "belated opportunity for social mobility" [32]. Finally, Smith et al. also explore to what extent these new programs help to address the gender imbalance in computing. They conducted a survey at five UK institutions and found that the degree-level apprenticeships themselves may not directly help to address the gender imbalance, but make several suggestions to improve the gender imbalance going forward, such as by advertising apprenticeships directly to women, as well as more widely [31].

\section{THIS WORK}

In this paper, we examine the newly established Graduate Apprenticeship (GA) program at a Scottish university. The program is currently in its second year of operation and, similar to a typical undergraduate degree in Scotland, awards a BSc in Software Engineering after four years. This program is of interest not simply because it incorporates work-based learning into a degree program in a novel way, but also as an example of a response to governmental incentives and existing pressures in the sector. These pressures are more clearly perceived in a "first look", in the early stages of the program, which provides an opportunity to understand it at its inception unclouded by an examination of "success" - whether, and how many, students graduate, etc.

It is no good if the government makes funding available, but universities do not want to pursue the opportunity, if it is unattractive to employers or unappealing to students. For a new program to "work", it must work for all parties involved. Our overarching research questions then are:

(1) Why did employers decide to participate in this novel degree program and how does it fit into their existing recruitment structures?

(2) What are students' individual learning trajectories that brought them to the program and how do they make sense of them?

(3) What work are students doing in their companies after only a year in the program?

To address these questions, we take a 360-degree view of this new degree program. We obtained ethical approval for, and draw on, three kinds of data as shown in Table 1 . We use pseudonyms throughout this paper, which remain consistent across the different sections.

At the time of these interventions, students had completed their first year in the program and were working at their companies prior to their return to university in the fall. In the following, we further describe the context of this program, before discussing the data we collected in detail.

Table 1: Data Collected

\begin{tabular}{l|l|l|l}
\hline Study & Participants & Data Collected & RQs \\
\hline $\begin{array}{l}\text { employer } \\
\text { consultation }\end{array}$ & $\begin{array}{l}\text { 29 employers in total, } \\
\text { of which 9 have ap- } \\
\text { prentices in the first } \\
\text { cohort of the program }\end{array}$ & $\begin{array}{l}\text { survey responses, } \\
\text { follow-up inter- } \\
\text { views }\end{array}$ & RQ1 \\
\hline life stories & 9 students & $\begin{array}{l}\text { life story inter- } \\
\text { views }\end{array}$ & RQ2 \\
\hline diary study & $\begin{array}{l}\text { all 32 students in the } \\
\text { program }\end{array}$ & $\begin{array}{l}\text { daily diaries over } \\
\text { a period of four } \\
\text { weeks }\end{array}$ & RQ3 \\
\hline
\end{tabular}

\subsection{Context is Confusing}

In some parts of the world, work-based learning has been firmly embedded in formal education at a variety of levels. In Germany, for example, apprenticeships were created as a formal scheme in the 1960s. Such schemes were a response to a concerns expressed by German industry, who predicted a degree of "academic drift": a shift away from teaching topics of close relevance to industry and towards theoretical, abstract, more "academic" ideas [17].

In the United Kingdom, apprenticeships are offered at several levels, which are the result of multiple reforms in the 1990s and 2000 s. Following a slow decline of apprenticeships from the 1960 s to the 1990s, the government established Modern Apprenticeships which typically last for two to four years, provide paid employment, and are equivalent to an A level qualification - in 1994 in the first major reform since the 20th century [18]. In the early 2000s, national frameworks that explain the minimum requirements for different apprenticeships were introduced [24]. For each sector, there are now one or more of these frameworks, which are developed by Sector Skills Councils in collaboration with employers. Since then, additional apprenticeship levels have been added, including, in 2015, the degree-level apprenticeships that are the focus of this study.

If one is not intimately familiar with this situation, this can be confusing. Two versions of essentially the same initiative were brought in at different times. They have different names in Scotland and the rest of the UK. They are presided over by entities that are transparently obvious to those who work with them (such as "Sector Skills Councils"), but to identify their role and influence to an outsider takes a great deal of careful explanation. And whilst the work reported here is rooted in that context, the wider point of this paper is not to exhaustively explore it, but rather to expose those elements that exist in many places - universities, students of different types and backgrounds, government initiatives - and show how those forces have played out in this situation. Thus, the wider example of responsive practice may be seen through other local lenses, with their own histories and funding forces.

\subsection{Design Considerations}

Following a consultation with employers [anonymous reference], the university decided to develop a Graduate Apprenticeship in Software Engineering. This degree complements its existing Computer Science and Software Engineering programs, which have been offered for several decades and have not undergone larger 
structural changes in response to concerns that CS degrees do not adequately prepare graduates for industry [28]. The Graduate Apprenticeship takes a different approach and explicitly combines part-time work and study. Students apply directly to their future employer, rather than the university, and study either in blocks of several weeks or as "day release" [6]. In the traditional day release model, students maintain their regular working schedule, but spend a limited amount of time in regular intervals (generally one day per week) at the university.

In contrast to other programs, the program we examine in this study was deliberately designed for students to study at university in eight-week blocks during the first two years of study. There were several reasons for this, some pedagogic, some pragmatic.

The pedagogic reasons included the belief that higher-level learning is not suited to short periods of attention and the rapid contextswitching that is inherent in traditional day-release models. Additionally, the team was keen to try and "capture the point of a university education" and so the eight-week blocks provided time for students to form a cohort in which students could work and study [anonymous reference]. A desired outcome of this design was for them to be able to contact their colleagues in other companies, to become a peer-group as they went forward, in the same way a typical graduate stays in touch with their peers as they progress in their career.

Pragmatic reasons included a consideration of the employers' context, in bringing the apprentices "up to speed" at the beginning of a program. Large companies, with several apprentices, have the resources to put on their own "boot camps", but that is not practical for the small companies with, perhaps, only a single apprentice. A mix of companies, especially the smaller enterprises, was essential to the overall ecosystem of the program, and so the initial block takes on that role. Additionally, the team had anecdotal knowledge that day release in other institutions tended to be packed full of lectures, creating a highly undesirable learning environment in which the period where the students could be talking to each other and with the staff was replaced with lectures: a largely one-way flow of information. The block structure provided both time and space for less formal, extended, interaction.

The final piece of pragmatics was to recognise that while the eight-week blocks scaffold the apprentices' learning in the early years, it was not a model that could be sustained throughout the program. By the last two years, the block structure with dedicated staff is not compatible with offering a good range of advanced options. At that point, the students will choose from a wide range of existing final-year and Masters-level courses on offer in the expectation that they will have become mature enough learners to be able to juggle day-release with their job.

\subsection{Program Details}

Students in the scheme begin by joining their companies. After spending the fall at the university, they return to their companies in January and February, before studying at university for another eight-week block. Figure 1 provides an overview of the program.

In the first year, courses focus on how to navigate large codebases, learning new programming languages, and professional software engineering practice. The second year covers a breadth of topics,

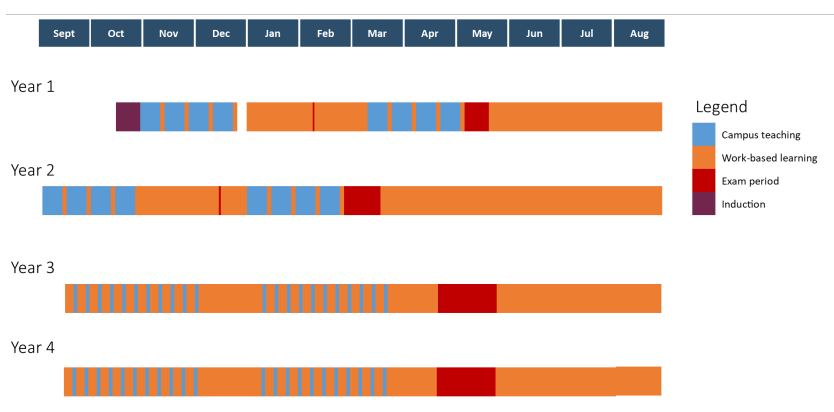

Figure 1: Graduate Apprenticeship Schedule

including computer architecture, networking and systems, as well as data science and human computer interaction. Finally, in years 3 and 4, students take classes in the traditional degree programs using the day release model.

Prior to start of the program, the university also offers a programming summer school in Python that is open to all and is optional by default. However, the vast majority of incoming apprentices take part in it.

\section{EMPLOYER CONSULTATION}

Prior to the development of its Graduate Apprenticeship program, the university ran a series of sessions with local employers. These sessions led to a formal consultation to develop the blueprint for a Software Engineering GA, which was held in the summer of 2018. All employers from the earlier sessions were invited to take part and, ultimately, 26 employers participated. The consultation asked about the size of the company, the average recruitment of new software engineers per year, how the Graduate Apprenticeship might fit with the company or organization, as well as expectations for mentoring in the workplace and whether support for other kinds of apprentices already existed.

In the first cohort of the program, there are currently $10 \mathrm{em}-$ ployers, ranging from smaller startups to the IT department at the university and a major financial services company. 6 of these 10 employers participated in the consultation. Additionally, some of them participated in follow-up interviews, which were conducted in the spring and summer of 2020 when the apprentices were already working in their companies. In the interviews, we were particularly interested in what kind of work the employers thought their apprentices were doing, whether they were receiving a return on their investment, and how they were planning to develop and train the students going forward. In the data presented below, we focus on the results from the 10 employers who recruited apprentices.

\subsection{Findings}

4.1.1 Goals \& Aims. As part of the consultation, employers were asked how they could see themselves using the Graduate Apprenticeship by choosing any of the following goals.

- To re-train staff in non-IT roles (2 employers)

- To upskill existing staff in software development or IT roles (4 employers) 
- To recruit school-leavers with basic computing/programming skills (5 employers)

Employers were also asked to rank their reasons for participating in a Graduate Apprenticeship as shown in Figure 2. Here, the most common reason was "to address a recognized future skills need", followed by "to enable unqualified but successful employees to get a qualification" and "to expand the workforce in current areas". Finally, "to get value out of the apprenticeship levy" and "to improve the productivity of existing employees" were the least popular reasons.

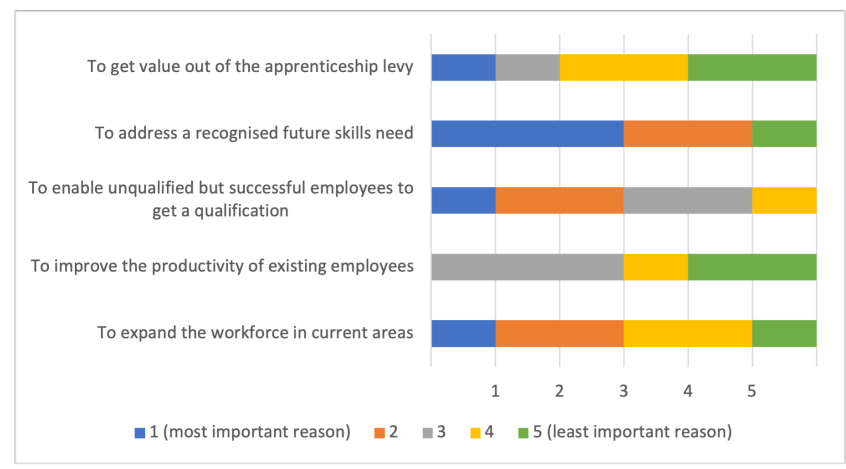

Figure 2: Reasons for Employers to Participate in the GA

Some employers also addressed their reasons for participating in the program in the follow-up interviews:

I think it was about giving that opportunity and understanding that there's a massive shortage in tech talent in the UK. And we wanted to be involved in growing that talent down different avenues, and just giving that person that opportunity that they might not otherwise have. And that's the key piece for us and not, oh actually yeah this is a good route for us, because we don't need to pay them as much or whatever. [software company 1]

Embedded in this are quotation many tacit features of the employers' context. There is a simple (and generally held) acceptance of the government's position that there is a "lack of talent". Against that, this particular employer positions themselves as good citizens - to the country and to the students. Finally, even with the government's imposition of the apprenticeship levy, they recognize and distance themselves from the assumption that the obvious reason for their involvement would be monetary advantage - indeed, for hardly any of the employers is this a primary reason for participation.

4.1.2 Existing Structures. The employers participating in the Graduate Apprenticeship differed in terms of their prior experience working with apprentices and, similarly, in terms of their existing support structures. Several had no prior apprentices in their companies or had only had students or interns.

Well, I suppose, to be honest my expectations were fairly loose to start with. We've done a lot of work as a company with, with students and interns and, you know, with varying degrees of success. [...] But then, of course, she [the apprentice] is in a more structured environment turning up at a course that is, obviously, giving her a lot of input that's relevant to what we do. [startup]

Some of the employers also offer traditional Modern Apprenticeships in addition to degree-level apprenticeships. Companies that only had Modern Apprentices reported having more informal support structures.

We have 3 Modern Apprentices in IT who are mentored by staff members. Support is quite informal though no training was provided for mentors. [public organization 1]

The Modern Apprentice scheme is great but it almost feels like sometimes you get a 16 year old thrown at your door and you run with it. [...] I feel that this [GA] program offers far more support. [transportation company]

On the other end of the spectrum, one employer had already partnered with another university to offer Graduate Apprenticeships and had developed structures to mentor and support apprentices.

The Graduate Apprentices are each given an onproject mentor and a university mentor which are sometimes the same person. They meet every fortnight as a group to discuss how university is going and any additional support that they require. Day to day they work on customer projects and are heavily involved in the software development lifecycle and constantly given stretch assignments by their project mentors. [large engineering firm]

The Graduate Apprenticeship program also led to additional support structures being developed by some employers:

$[\ldots]$ we recognised very early that to give people the time to do what they need to do - to support these individuals and mentor these individuals, to spend time doing that knowledge sharing with their programming we have to give them the capacity to do that. We have to give them the time to do that, so we created an emerging talent project code and anybody who spends any time with any of the apprentices, logs that as emerging talent time. [public organization 1]

While we may sometimes refer to "the employers" in unitary manner, those participating in the Graduate Apprenticeship program are more varied than one might expect, ranging from a small startup with few employees to large organizations with existing processes for onboarding and mentorship. The structure of this Graduate Apprenticeship then appears to work for many different types of employers.

\section{LIFE STORIES}

Governments might establish programs to address country-level issues (a perceived lack of "work-ready" computing graduates), universities may respond (to remain competitive), and companies may sign up to this (with little to lose). But if there are not students 
interested to pursue this route, or the offerings are unattractive, the initiative fails before it starts. It is fair to say that the existence of a recruitment pool was very much a case of "educated guesswork" on the part of all parties.

In this section, we use a narrative approach to explore the backgrounds, motivations, and wider learning trajectories of the students in this program. Many of the students we interviewed took unusual paths to the Graduate Apprenticeship - several of them had previously unsuccessful experiences in higher education - and the program provided an opportunity for them to pursue the career in computing that they had been seeking.

\subsection{Methodology}

We adopt an autobiographical approach, which views "identity as a long-term personal project, more situated in the person than the situation, and oriented toward developing a coherent story across an individual's past, present, and imagined future." [34] Narrative identity of this nature provides "a theoretical framework, a methodological technique, and an analytic approach" for this study [1] Indeed, the work reported here is specifically concerned with participants' "learning life" - that is, with the stories they tell about their learning experiences. Such approaches have previously been used in computing education research [anonymized references]. A learning life includes prior experiences, from solving problems as a child at the kitchen table to time spent in school and university, as well as learning in the workplace in the present day and ideas about the future.

We contacted all 32 students in the program with an invitation to participate in this part of the study. We ultimately conducted interviews with nine participants using a modified version of the life story interview developed by Dan McAdams [23].

I'd like you to think about your learning career, your learning 'life', as if it were a book. Each part of your learning composes a chapter in the book. Certainly the book is unfinished at this point: still, it probably contains a few interesting and well-defined chapters. Please divide your learning 'life' into its major chapters and briefly describe each chapter. You may have as many or as few as you like, but I'd suggest at least 2 or 3 and at most 7 or 8 . Think of this as a general table of contents for your book. Please give each chapter a name and describe its overall contents.

In contrast to other approaches, such as semi-structured interviews, these learning life story interviews are largely open-ended and explore individual participants' wider learning trajectories. Interviews were recorded, professionally transcribed, and imported into the qualitative data analysis package NVivo. As part of our analytic approach, we conducted a thematic analysis. One of the authors repeatedly read through the interviews and purposefully identified themes related to our area of interest (students' individual learning trajectories). We also remained open to additional themes that emerged in this process. The themes were then discussed with another author and any disagreements were resolved through discussion.
Table 2: Interviewee Paths to the Graduate Apprenticeship

\begin{tabular}{|c|c|c|}
\hline Name $^{1}$ & Path & Employer \\
\hline $\begin{array}{l}\text { Sophie } \\
\text { MacIntyre }\end{array}$ & joined after school & $\begin{array}{l}\text { large engineering } \\
\text { firm }\end{array}$ \\
\hline David Simon & joined after school & $\begin{array}{l}\text { university IT } \\
\text { department }\end{array}$ \\
\hline $\begin{array}{l}\text { Bryan } \\
\text { Stephens }\end{array}$ & in employment & $\begin{array}{l}\text { large financial } \\
\text { services company }\end{array}$ \\
\hline $\begin{array}{l}\text { Colin } \\
\text { Townsend }\end{array}$ & in employment & $\begin{array}{l}\text { public } \\
\text { organization } 1\end{array}$ \\
\hline Jamie Gibbs & $\begin{array}{l}\text { previously completed } \\
\text { another degree }\end{array}$ & startup \\
\hline Page McNeal & $\begin{array}{l}\text { previously completed } \\
\text { another degree }\end{array}$ & $\begin{array}{l}\text { public } \\
\text { organization } 1\end{array}$ \\
\hline Luke Samuels & $\begin{array}{l}\text { previously completed } \\
\text { another degree }\end{array}$ & $\begin{array}{lr}\text { large financial } \\
\text { services company }\end{array}$ \\
\hline $\begin{array}{l}\text { Christopher } \\
\text { Langdon }\end{array}$ & $\begin{array}{l}\text { dropped out of higher } \\
\text { education }\end{array}$ & $\begin{array}{lr}\text { large financial } \\
\text { services company }\end{array}$ \\
\hline $\begin{array}{l}\text { Dave } \\
\text { Millhouse }\end{array}$ & $\begin{array}{l}\text { dropped out of higher } \\
\text { education }\end{array}$ & $\begin{array}{l}\text { public } \\
\text { organization } 1\end{array}$ \\
\hline
\end{tabular}

\subsection{Findings}

We identified themes broadly related to two areas: students' paths to the Graduate Apprenticeship, including their prior experiences at university, and the ways in which they sought out opportunities like the apprenticeship. In the following, we describe these themes in more detail.

5.2.1 Paths to the Graduate Apprenticeship. The students we interviewed took different paths to the Graduate Apprenticeship, as shown in Table 2. Two of them came straight from school, but the majority had unsuccessful previous experiences in higher education: They had either dropped out of university or completed a degree but found that it did not always enable them to pursue the career that they were seeking. These previous experiences were not in computing, but often in adjacent majors, such as mathematics, engineering, video game design, and art and design.

And then afterwards it was, kind of, like, "what am I going to do with this?” Because you can't get a programming job, by saying, like, "oh I've done it myself in art and design.” [Page McNeal]

So I went into uni after college and I went in to do games design at [another institution] and the first thing we were told when we went in was, "you're not going to get a job at the end of this." [Luke Samuels]

Finally, two participants, Colin Townsend and Bryan Stephens, had previously attended university and were already in a settled job when they applied for the Graduate Apprenticeship program. In Colin Townsend's case, the Graduate Apprenticeship was offered by his employer and provided an opportunity for him to transition into a more technical role he had been seeking.

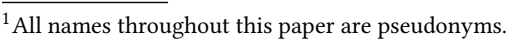


Table 3: Student Paths to the Graduate Apprenticeship

\begin{tabular}{l|l}
\hline I joined the program straight from school. & 10 \\
\hline $\begin{array}{l}\text { I joined after working for a while but went to university } \\
\text { or college more than a year before starting the GA. }\end{array}$ & 9 \\
\hline $\begin{array}{l}\text { I joined the program straight after studying at college } \\
\text { (within a year of starting the GA). }\end{array}$ & 6 \\
\hline $\begin{array}{l}\text { I joined the program straight after studying at university } \\
\text { (i.e. for another degree, or part of one, within a year of } \\
\text { starting the GA). }\end{array}$ & 4 \\
\hline $\begin{array}{l}\text { I joined after completing another apprenticeship. } \\
\text { I joined after working for a while and haven't gone to } \\
\text { university or college before. }\end{array}$ & 1 \\
\hline
\end{tabular}

These paths are similar to those of the overall cohort in the Graduate Apprenticeship, as shown in Table 3.

5.2.2 Feelings of Isolation \& Day Release Challenges. Participants who had previously attended university but ended up leaving higher education described negative experiences and feelings of isolation. These experiences are familiar in the literature [7]. For instance, Veilleux et al. observe that "Supporting a student's sense of belonging both to the discipline and their supportive communities can improve the academic resilience of computer science students, thus improving retention." [36]

So, say I had a problem and I was stuck on something [...], I felt like I couldn't really ask anyone. Like, for help. [...] I just felt really isolated from the people who are there to help you. And then, second year, just, I started not turning up and stuff like that and everything went downhill and it just didn't really work out. I failed. I got withdrawn. [Dave Millhouse]

I didn't find it so great. I think I was there just a few months. [...] And computing science was... like, it sounds stupid but it was a load of guys. I think there was like two hundred of us and I think about four of us were girls... [Page McNeal]

A related example is the experience of Bryan Stephens, who had previously studied in the day release model as part of an apprenticeship with another company. For him, this model had significant drawbacks, including similar feelings of isolation.

I think my [day release] day was a Tuesday and $[\ldots]$ as soon as you left that day the lecturers didn't want to hear from you. If you did email them, you didn't get any response until the following week, and then there was a really intense day. Because they had to cram in a full week's work into one day. So, I did not enjoy that at all. You just didn't really feel like a part of it [...]. [Bryan Stephens]

5.2.3 Purpose of a University Education. Some participants also reflected on what they had perceived as a "natural" progression from school to university, following a path that was expected of them [anonymous reference].
I didn't really have a strong desire to go and do maths at university, it was just I guess almost expected: you do well at A-levels, you go to university. It was like I was good at maths at A-level, so I'll do maths at uni. [Colin Townsend]

Interviewer: How did you decide on [your major]? Respondent: So, that was dumb as well. That was just something my dad said was a good idea. Oh, civil engineers are paid well. - Oh, okay, well, I'll do that. [Christopher Langdon]

The apprenticeship stood in contrast to this:

So, I guess with the Graduate Apprenticeship, it gave me a goal in mind and it gave me an end point; I'm doing this for this specific reason. To have a job here, to have a qualification under my belt, after four years, plus with the work experience as well. So, the difference was, I've got an end point. [Dave Millhouse]

5.2.4 Finding the Graduate Apprenticeship: Alert to Opportunities. Participants expressed different reasons for pursuing a Graduate Apprenticeship, including the desire for a position designed to support their learning, the ability to gain immediate work experience, and being able to afford their studies. Indeed, for many participants who were looking for a way into the discipline, the apprenticeship provided immediate access to what they had been seeking.

And I ended up looking it up and I was, like, this looks, kind of, ideal for what I want. I can get straight in there and start doing the actual work after playing about for so long, basically. [...] I see it as a little second chance. [Page McNeal]

The work experience the apprenticeship offers was an incentive even for those who had already completed a degree or were working at a company.

I thought about it and I was like, if I want to be a developer then this seems like the best opportunity to do it, I could learn on the job. [Colin Townsend]

We found that apprentices were not passive in their interests, but rather alert to opportunities in a field they knew they wanted to work in. In this, their path and decision to pursue the apprenticeship was different from pursuing a traditional degree at university.

And I always had a separate search for software development and trying to get back into it. And it was always that kind of, how can I move now and not take the financial cut? [Bryan Stephens]

When I was working at the supermarket, me and my mum kept an eye out on different websites to see if there was anything that was kind of like uni, but not like uni, because obviously, uni, didn't really work out for me, like just solely uni. [Dave Millhouse]

5.2.5 Experiences with Alternative Programs. Three participants - Colin Townsend, Bryan Stephens, and Christopher Langdon sought different paths into the discipline through structured programs, such as boot camps or study with the Open University, which offers distance education programs in the UK. However, they 
found that these were not suitable in terms of time commitment and financial tradeoffs required.

I thought, that looks like a very intense course, so I'd asked [and] they went "really you are probably better having somebody that can maybe financially support you." And it was Monday to Friday, nine to five, and you are working at night as well. So, I was like: "No, I just can't do that." [Bryan Stephens]

Because it was a part-time course because I couldn't afford to give up my job, it was going to take six years to get the degree. And then my girlfriend [...] found [my company's] Graduate Apprenticeship program. And there was one for software development, and then they would pay you a salary at the same time as going to uni, and it would only take four years and not six years. [Christopher Langdon]

5.2.6 Attractive Job Descriptions. For many participants, the nature of the job descriptions was also part of what attracted them to the program.

The post was advertised almost as if you wanted a change of career. So they were trying to encourage people from different backgrounds who'd maybe not worked in tech to come into it [...]. [Luke Samuels]

And the website made it seem like it was tailor made for me because there was a whole page on, have you tried uni before, did you suck at it, are you getting old, do you want to change the things that you're doing in your life. And I was like, tick, tick, tick. [Christopher Langdon]

Apart from the specific aspects noted above - such as students' prior experiences at university and what attracted them to the Graduate Apprenticeship program - what is noticeable about these students' trajectories is that few of them are traditional university entrants, transitioning directly from school. Instead, many of them have prior experiences in work or study, which emerge in their life stories. It does not appear, then, that the Graduate Apprenticeship is detracting from the recruitment pool for mainstream degree offerings, but is rather augmenting it, offering an additional opportunity.

\section{DIARY STUDY}

There is great meaning in work. In what people do, day-to-day, in why they do it and why they want to do it, what they want to be part of. We were interested to investigate the kind of daily work that Graduate Apprenticeship students undertake in their respective companies and at university - and what this means to them. To do so, we used a diary study methodology to send repeated, small elicitations to participants [2, 9, 13].

\subsection{Methodology}

Diaries are an example of non-storied narrative approaches that elicit "authentic details without necessarily being concerned with larger trajectories." [anonymous reference]. This stands in contrast to more storied approaches, such as the life stories in section 5 , which tend to expose longer term trajectories and the meaning narrators make of their experiences [anonymous reference].

To date, diary studies have not commonly been used in computing education research, but they are often found in human computer interaction (HCI) and computer-supported collaborative work (CSCW) $[11,25]$. In these fields, diary studies can take wide a range of approaches. Kaufmann and Peil identify a number of differentiating factors among diary studies [19], including whether diaries are solicited or unsolicited, unstructured or highly structured, the duration of intervention (and, with it, how often diary entries are collected, ranging from every 30 minutes to once a month [13, 27]), whether they are collected in situ or are reconstructive, as well as what additional supporting materials and documenting tools are used (ranging from pen-and-paper, to email and survey diaries, and voice recordings [25]). Some studies also include debriefing interviews, either at the end of each day or upon conclusion of the study [22, 27].

Our diary study design was influenced by a study conducted by Amabile and Kramer, as well as work in computing education by Fincher. In their work, Amabile and Kramer sent small, daily questionnaires to a large number of participants to explore how events on project teams affect the experience, motivation, and progress of team members [4]. They collected this data over the course of an entire project, which, depending on the team, lasted between 9 and 39 weeks [3]. Fincher used diaries inspired by the Mass Observation project in the United Kingdom as part of the Sharing Practice project to examine the life of academics in computing, in particular with regard to their teaching and changes to their teaching practice [13]. Her participants kept a diary (a "day survey") once per month over the course of a year.

The use of diaries has several benefits: First, it helps to obtain participants' responses closer to the reported events when they occurred, rather than after the fact [22]. Second, it tends to produce detailed information about the area under investigation [22], provides "insight into taken-for-granted activities", and access to tacit knowledge [2]. As Wheeler and Reis write, diaries capture the "little experiences of everyday life that fill most of our working time and occupy the vast majority of our conscious attention" [38]. Third, it permits an investigation of developments and trends over time, such as in the work our apprentices are doing, and in how they perceive the relationship between their work at the company and their study at university. As Amabile and Kramer note: "because we gathered daily data from each participant over several weeks, we were able to see patterns in events and inner work life over time." [4] And Markham and Couldry similarly observe that diaries can reveal: "the complex, sometimes conflicted ways in which opinions are formed and questioned can be tracked." [22]

\subsection{This Study}

We sent daily questionnaires to all 32 students in the Graduate Apprenticeship for a period of four weeks. We were particularly interested in the day-to-day experiences of students in the program and chose to elicit diary entries on a daily basis. We limited the intervention to four weeks in order to avoid diary fatigue.

We used a narrative prompt inspired by Amabile and Kramer's Detailed Event Narrative Analysis and the self-signification approach 
Table 4: Diary Participants and Entries

\begin{tabular}{|l|l|l|l|l|}
\hline & \multicolumn{2}{|l|}{ Participants } & Entries \\
\hline Entries & Number & Percentage & Number & Percentage \\
\hline 0 & 1 & $3 \%$ & 0 & $0 \%$ \\
\hline$\ldots$ & & & & \\
\hline 5 & 1 & $3 \%$ & 5 & $1 \%$ \\
\hline$\ldots$ & & & & \\
\hline 12 & 2 & $6 \%$ & 24 & $4 \%$ \\
\hline 13 & 1 & $3 \%$ & 13 & $2 \%$ \\
\hline 14 & 1 & $3 \%$ & 14 & $3 \%$ \\
\hline 15 & 2 & $6 \%$ & 30 & $5 \%$ \\
\hline 16 & 2 & $6 \%$ & 32 & $6 \%$ \\
\hline 17 & 2 & $6 \%$ & 34 & $6 \%$ \\
\hline 18 & 1 & $3 \%$ & 18 & $3 \%$ \\
\hline 19 & 6 & $19 \%$ & 114 & $21 \%$ \\
\hline 20 & 13 & $41 \%$ & 260 & $47 \%$ \\
\hline Total & $\mathbf{3 2}$ & $\mathbf{1 0 0} \%$ & $\mathbf{5 4 9}$ & $\mathbf{1 0 0 \%}$ \\
\hline
\end{tabular}

associated with the SenseMaker project, in which participants themselves assign meaning to a narrative [5, 35]. The daily questionnaires Amabile and Kramer used contained several fields. They included a description of the work a participant had done today, several scale-based answers, a specific event description, as well as an open prompt to add anything else they wanted to report [5]. Our approach for this study was to reduce the number of fields as much as possible in order to allow students to complete the form quickly The resulting questionnaire contained four elements and we focus our discussion in this paper on the first and fourth question:

(1) In a few sentences, tell us about the work you did today.

(2) To what extent did you use university-acquired knowledge today? (On a scale of 0-6 or not applicable.)

(3) To what extent did you use workplace-acquired knowledge today? (On a scale of 0-6 or not applicable.)

(4) Please add anything else that you would like to report today

Students were sent an email with an invitation to complete their workplace diary around 16:30 each weekday. If they did not complete the survey on one day, they were reminded to do so at around 9:30 the following day.

We collected a total of 549 diary entries from 32 students in the Graduate Apprenticeship program, as shown in Table 4. Of the 32 participants, there was one who did not submit any entries at all. Additionally, there was one participant who was on furlough for the duration of the study, but still submitted entries indicating this. Some participants took parts of their annual leave during this period of diary collection, many of them indicated this in an entry. Of the 549 entries, 59 did not include experiences in the workplace and instead mentioned being on furlough or annual leave. (Although some participants also described studying for class while on annual leave.) Overall, 13 participants completed all entries and the average number of entries per participant was 17 out of 20 possible entries.

We returned students' diary submissions to them after two weeks and at the end of the study, both to express our appreciation for their participation and in anticipation that they may find them useful in looking back at their experiences, especially in coursework related to reflection and professional practice. Fincher has previously written about sharing findings and themes with diary study participants [14].

As before, we analyzed the diaries by looking for themes related to our area of interest (the kinds of work students were doing in their companies).

\subsection{Findings}

We found that the work that the diarists are doing exemplifies Lave and Wenger's notion of Legitimate Peripheral Participation [21]. This term describes a form of authentic learning whereby an apprentice works on "real work". Their participation - whether in a tailor shop or a software company - is legitimate in that it is directly related to the business of the enterprise, but peripheral in that they don't work on artefacts of high value or that are mission critical. Apprentices work at the edges, on the periphery, getting to know customers, company protocols, and tool chains.

For instance, some participants reported making straightforward improvements to their code.

Today I mainly just went over the html I had done a wee while ago and made some improvements (David Bourne, June 15)

Bug fixes and boredom mostly. There weren't many bugs left and with little else to do, it was a quiet boring day (Jamie Gibbs, June 24)

This included refactoring existing code:

Today was a lot of conditional statements and refactoring. (Page McNeal, July 8)

Others described mainly writing documentation:

Today I worked on updating parts of the frontend to display new information and also writing documentation to explain the rules used to generate different parts of the screen. (David Simon, June 30)

In many cases, the apprentices were working on existing tickets to address problems in the code. For some, such as Stewart Bennett, this took place over several days and included steps such as debugging code, discussing potential solutions among his team, and committing changes.

Today involved debugging code to find the origin of a bug that was discovered after the release. After locating the issue was a faulty piece of code that had only worked by chance for previous years, we organised for a team call to be set up to discover what should be implemented to fix the bug. (Stewart Bennett, June 23)

Backtracked where the code that was causing an issue was called to ensure a fix wouldn't break functionality of other aspects of the code (Stewart Bennett, June 24)

Committed changes for returner issue to release branch and got the tag for the build afterwards to be put into a testing environment. (Stewart Bennett, June 25) 
However, we did not only find examples of students fixing existing issues, but also raising new problems and then subsequently communicating with other teams responsible for addressing them.

Conversations with Business analysts in scrum calls to discuss whether a defect that I have raised can be rejected this release as it was an existing defect and not produced in this project release. (Tyler Atkinson, June 23)

Dev team couldn't recreate a defect that was raised, so asked if we could recreate it, which we could and assigned it back to them. Also Retesting defects that dev had fixed. (Tyler Atkinson, June 25)

After making changes to their code, apprentices also engaged in code review, both having their code reviewed by others and reviewing the code others had submitted.

Every time a pull request is made when a ticket is complete, the lead developer has to read over the code and then accept the pull request if it is satisfactory. In this case, the code I made was not up to standard - and had a few minor changes to make. (Lisa Curtis, June 20)

Looked into the cause of a text error on the user end of the application and found a solution, committing it and moving the story to code review. Also code reviewed some stories and looking into causes of errors occurring in the live environment (Stewart Bennett, June 30)

Finally, many tasks in this category were related to testing. The diarists often reported testing existing functionality or writing additional unit tests in their diaries.

[My colleague] has written some Unit tests in the master branch which i can have a look at for inspiration and tomorrow we will review what i've done. (Michael Potter, July 7)

Then [the colleague] and myself reviewed the Unit tests [...], which i had done differently to how [he] would have done them. So he actually gave me a very helpful layout that he uses when writing unit tests. (Michael Potter, July 8)

Today I've managed to write all of the Unit tests [...], however [the colleague] was away on leave today so tomorrow we will have a webex call to discuss what i've done and whether or not i have written the tests correctly. (Michael Potter, July 9)

Many of the tasks the diarists describe are similar to those that Begel and Simon identify in their work on novice software developers [8]. They draw on and revise a taxonomy of software developer activities originally developed by Ko et al. [20]. Begel and Simon observe: "As we began observation, it became clear that our subjects were engaged in much more than programming-related tasks." [8] Indeed, the work we saw diarists doing often involved working on bugs, testing, documentation, tools, and communication.

Legitimate Peripheral Participation also describes the process of becoming increasingly involved in a practice as one becomes more experienced [21]. We saw elements of this in the diarists' engagement in their work, for example when supporting a colleague while pair programming or in taking on more substantial projects.

Had a session with someone to mentor/pair-program. Helped them merge a change from someone else on GitHub and went through some errors, and highlighting solutions. [...] (Daniel Low, July 6)

A lot of my previous work was building on top of existing code and extending the functionality or refactoring. This project is the first time I've properly had to create a lot of code from scratch, so it was quite intimidating to work on. At the end of the day, I'm quite happy with what was done however still feel it's going to be a while till I feel more comfortable on stories like this. (Colin Townsend, June 15)

The diarists give us a close-grained understanding of the work that is in front of them, that is on the apprentices' desks. However, a limitation of this method is that it is less likely to illuminate work that is not the current focus, that is not being conducted day-to-day. When we solicited the diaries, the university was distant in time and space, and the diarists reflected little on the work they were doing there. This study, then did not allow us to address the question "to what extent did you use university-acquired knowledge today?”

\section{DISCUSSION}

This study has been an exploration of the inception of a new degree program, with the university choosing to develop and to offer it, employers deciding to become active partners in its operation, and students beginning to enroll in it.

The students we interviewed took unusual paths to studying computing. Many of them had prior experiences at university, but ended up leaving higher education. Not all of them were previously computing students, but the newly created Graduate Apprenticeship program provided an opportunity - "a little second chance" for them to overcome barriers to pursue the career in computing that they had been seeking. This differs from prior work, where Smith et al. found that "many of the apprentices were using the opportunity to gain a recognised award, rather than as a vehicle to embark upon a new career." [30] This may be due to self-selection among the participants in this study from the broader cohort of students or it may be due to differences in the program itself.

Indeed, certain aspects of this Graduate Apprenticeship program may be more likely to attract students with this kind of background. In particular, some of the practices presented here, such as structuring the program in blocks of several weeks and job descriptions that appeal directly to those with an interest in technology but limited prior experience, could then be of value to other programs. However, to date, there has only been limited work about institutional differences in the implementation of degree-level apprenticeship programs, which presents an opportunity for future work.

\section{CONCLUSIONS}

One of the challenges in education research is that it is inherently difficult to generalize practices, as they are highly context dependent and cannot be easily replicated. "Generalizations are, as such, of small avail, unless they bring us back with increased purpose and 
understanding to the particular and to the 'particular' that matters most in the interest of knowledge [...]." [37] The aim of this work was not to make generalizable claims about this program, but to provide a rich contextual exploration of it. As Borrego et al. observe: "the thick description of [a] single case allows readers to identify elements that can be transferred to their own situations." [10]

To do so, we have used a unique set of methods that provide a 360 -degree view of this novel work-based degree program by incorporating the perspectives of different stakeholders - the university, employers, and students - and by exploring students' individual paths to the program, as well as their day-to-day experiences in it. It is our hope that this work contributes not only a "first look" at the Graduate Apprenticeship in its context, but also that these methods will allow others to report on their own programs.

\section{REFERENCES}

[1] Jonathan M. Adler. 2017. Bringing the (Disabled) Body to Personality Psychology: A Case Study of Samantha. Fournal of Personality (2017), 1-22. https://doi.org/ 10.1111/jopy. 12364

[2] Andy Alaszewski. 2006. Using Diaries For Social Research. Sage, London, UK.

[3] Teresa M. Amabile, Sigal G. Barsade, Jennifer S. Mueller, and Barry M. Staw. 2005 Affect and Creativity at Work. Administrative Science Quarterly 50, 3 (Sept. 2005) 367-403. https://doi.org/10.2189/asqu.2005.50.3.367

[4] Teresa M. Amabile and Steven J. Kramer. 2011. The Progress Principle: Using Small Wins to Ignite foy, Engagement, and Creativity at Work (1 edition ed.). Harvard Business Review Press, Boston, Mass.

[5] Teresa M. Amabile, Jennifer S. Mueller, and Susan M. Archambault. 2003. Coding Manual For the DENA Coding Scheme (Detailed Event Narrative Analysis). Technical Report 03-079. Harvard Business School, Boston.

[6] Matthew Barr and Jack Parkinson. 2019. Developing a Work-Based Software Engineering Degree in Collaboration with Industry. In Proceedings of the 1st UK \& Ireland Computing Education Research Conference (UKICER). Association for Computing Machinery, Canterbury, United Kingdom, 1-7. https://doi.org/10. $1145 / 3351287.3351292$

[7] Roy F. Baumeister and Mark R. Leary. 1995. The Need to Belong: Desire for Interpersonal Attachments as a Fundamental Human Motivation. Psychological Bulletin 117, 3 (1995), 497-529. https://doi.org/10.1037/0033-2909.117.3.497

[8] Andrew Begel and Beth Simon. 2008. Novice Software Developers, All over Again In Proceedings of the Fourth International Workshop on Computing Education Research (ICER '08). ACM, New York, NY, USA, 3-14. https://doi.org/10.1145/ 1404520.1404522

[9] Niall Bolger, Angelina Davis, and Eshkol Rafaeli. 2003. Diary Methods: Capturing Life as It Is Lived. Annual Review of Psychology 54, 1 (Feb. 2003), 579-616. https://doi.org/10.1146/annurev.psych.54.101601.145030

[10] Maura Borrego, Elliot P. Douglas, and Catherine T. Amelink. 2009. Quantitative, Qualitative, and Mixed Research Methods in Engineering Education. Fournal of Engineering Education 98, 1 (Jan. 2009), 53-66. https://doi.org/10.1002/j.21689830.2009.tb01005.x

[11] Barry A. T. Brown, Abigail J. Sellen, and Kenton P. O'Hara. 2000. A Diary Study of Information Capture in Working Life. In Proceedings of the SIGCHI Conference on Human Factors in Computing Systems (CHI '00). Association for Computing Machinery, The Hague, The Netherlands, 438-445. https://doi.org/10.1145/ 332040.332472

[12] Richard K. Coll and Chris Eames (Eds.). 2004. International Handbook for Cooperative Education: An International Perspective of the Theory, Research, and Practice of Work-Integrated Learning. World Association for Cooperative Education.

[13] Sally Fincher. 2012. Using Narrative Methodology. University of Kent at Canterbury, Canterbury.

[14] Sally Fincher. 2013. The Diarists' Audience. In Documents of Life Revisited Narrative and Biographical Methodology for a 21st Century Critical Humanism, Professor Liz Stanley (Ed.). Ashgate Publishing, Ltd., 77-92.

[15] Sally Fincher and Janet Finlay. 2016. Computing Graduate Employability: Sharing Practice. Technical Report. Council of Professors and Heads of Computing.

[16] Sally Fincher and Daniel Knox. 2013. The Porous Classroom: Professional Practices in the Computing Curriculum. Computer 46, 9 (Sept. 2013), 44-51. https://doi.org/10.1109/MC.2013.261

[17] Lukas Graf. 2016. The Rise of Work-Based Academic Education in Austria Germany and Switzerland. Journal of Vocational Education \& Training 68, 1 (Jan. 2016), 1-16. https://doi.org/10.1080/13636820.2015.1107749

[18] Terence Hogarth, Lynn Gambin, and Chris Hasluck. 2012. Apprenticeships in England: What Next? Journal of Vocational Education \& Training 64, 1 (March 2012), 41-55. https://doi.org/10.1080/13636820.2011.590221
[19] Katja Kaufmann and Corinna Peil. 2020. The Mobile Instant Messaging Interview (MIMI): Using WhatsApp to Enhance Self-Reporting and Explore Media Usage in Situ. Mobile Media \& Communication 8, 2 (May 2020), 229-246. https://doi. org $/ 10.1177 / 2050157919852392$

[20] Amy J. Ko, Robert DeLine, and Gina Venolia. 2007. Information Needs in Collocated Software Development Teams. In 29th International Conference on Software Engineering (ICSE'07). IEEE, Minneapolis, MN, USA, 344-353. https: //doi.org/10.1109/ICSE.2007.45

[21] Jean Lave and Etienne Wenger. 1991. Situated Learning: Legitimate Peripheral Participation (1st edition ed.). Cambridge University Press, Cambridge, England; New York.

[22] Tim Markham and Nick Couldry. 2007. Tracking the Reflexivity of the (Dis)Engaged Citizen: Some Methodological Reflections. Qualitative Inquiry 13, 5 (July 2007), 675-695. https://doi.org/10.1177/1077800407301182

[23] Dan P. McAdams. 2008. The Life Story Interview.

[24] James Mirza-Davies. 2015. Apprenticeships Policy, England Prior to 2010. Briefing Paper 07266. House of Commons Library, London, UK.

[25] Leysia Palen and Marilyn Salzman. 2002. Voice-Mail Diary Studies for Naturalistic Data Capture under Mobile Conditions. In Proceedings of the 2002 ACM Conference on Computer Supported Cooperative Work (CSCW'02). Association for Computing Machinery, New Orleans, Louisiana, USA, 87-95. https://doi.org/10.1145/587078. 587092

[26] Philip Powell and Anita Walsh. 2018. Whose Curriculum Is It Anyway? Stakeholder Salience in the Context of Degree Apprenticeships. British Educational Research fournal (Sept. 2018), 90-106. https://doi.org/10.1111/hequ.12149@10. 1111/(ISSN)1469-3518.World-Teachers-Day-18

[27] John Rieman. 1993. The Diary Study: A Workplace-Oriented Research Tool to Guide Laboratory Efforts. In Proceedings of the INTERACT '93 and CHI '93 Conference on Human Factors in Computing Systems (CHI '93). Association for Computing Machinery, Amsterdam, The Netherlands, 321-326. https://doi.org/ $10.1145 / 169059.169255$

[28] Nigel Shadbolt. 2016. Shadbolt Review of Computer Sciences Degree Accreditation and Graduate Employability. Technical Report IND/16/5. Department for Business, Innovation \& Skills; Higher Education Funding Council for England.

[29] Kimberly Anne Sheen, Jillian Griffiths, Derren Wilson, and Stuart Cunningham. 2021. A Novel Pandemic Delivery Pattern for a New Digital User Experience Degree Apprenticeship. In Advances in Creativity, Innovation, Entrepreneurship and Communication of Design (Lecture Notes in Networks and Systems), Evangelos Markopoulos, Ravindra S. Goonetilleke, Amic G. Ho, and Yan Luximon (Eds.). Springer International Publishing, Cham, 335-342. https://doi.org/10.1007/9783-030-80094-9 40

[30] Sally Smith, Martha Caddell, Ella Taylor-Smith, Colin Smith, and Alison Varey. 2020. Degree Apprenticeships - a Win-Win Model? A Comparison of Policy Aims with the Expectations and Experiences of Apprentices. Fournal of Vocational Education \& Training 0, 0 (March 2020), 1-21. https://doi.org/10.1080/13636820. 2020.1744690

[31] Sally Smith, Ella Taylor-Smith, Khristin Fabian, Matthew Barr, Tessa Berg, David Cutting, James Paterson, Tiffany Young, and Mark Zarb. 2020. Computing Degree Apprenticeships: An Opportunity to Address Gender Imbalance in the IT Sector?. In 2020 IEEE Frontiers in Education Conference (FIE). 1-8. https: //doi.org/10.1109/FIE44824.2020.9274144

[32] Sally Smith, Ella Taylor-Smith, Khristin Fabian, Mark Zarb, James Paterson, Matthew Barr, and Tessa Berg. 2021. A Multi-Institutional Exploration of the Social Mobility Potential of Degree Apprenticeships. Fournal of Education and Work (July 2021), 1-16. https://doi.org/10.1080/13639080.2021.1946494

[33] Ella Taylor-Smith, Sally Smith, Khristin Fabian, Tessa Berg, Debbie Meharg, and Alison Varey. 2019. Bridging the Digital Skills Gap: Are Computing Degree Apprenticeships the Answer?. In Proceedings of the 2019 ACM Conference on Innovation and Technology in Computer Science Education (ITiCSE '19). Association for Computing Machinery, Aberdeen, Scotland Uk, 126-132. https://doi.org/10. 1145/3304221.3319744

[34] Avril Thorne. 2004. Putting the Person into Social Identity. Human Development 47, 6 (2004), 361-365. https://doi.org/10.1159/000081038

[35] Susara E. Van der Merwe, Reinette Biggs, Rika Preiser, Charmaine Cunningham, David J. Snowden, Karen O'Brien, Marcus Jenal, Marietjie Vosloo, Sonja Blignaut, and Zhen Goh. 2019. Making Sense of Complexity: Using SenseMaker as a Research Tool. Systems 7, 2 (June 2019), 25. https://doi.org/10.3390/systems7020025

[36] Nanette Veilleux, Rebecca Bates, Cheryl Allendoerfer, Diane Jones, Joyous Crawford, and Tamara Floyd Smith. 2013. The Relationship between Belonging and Ability in Computer Science. In Proceeding of the 44th ACM Technical Symposium on Computer Science Education (SIGCSE '13). Association for Computing Machinery, Denver, Colorado, USA, 65-70. https://doi.org/10.1145/2445196.2445220

[37] Robert Waller. 1962. Prophet of the New Age: The Life and Thought of Sir George Stapledon. Faber \& Faber, London, UK.

[38] Ladd Wheeler and Harry T. Reis. 1991. Self-Recording of Everyday Life Events: Origins, Types, and Uses. Fournal of Personality 59, 3 (1991), 339-354. https: //doi.org/10.1111/j.1467-6494.1991.tb00252.x 